\title{
Pengaruh Media Audio Visual Gerak Terhadap Kemampuan Bercerita Anak Kelompok B Di TK ABA 06 Cabang Medan
}

Received : 10 Maret 2020

Revised : 20 April 2020

Accepted : 2 Juni 2020

\author{
Ade Kurnia Sari ${ }^{1}$, Nurmaniah ${ }^{2}$ \\ Fakultas Ilmu Pendidikan \\ Universitas Negeri Medan \\ Jln. Willem Iskandar Psr V Medan Estate \\ E-mail : $\underline{\text { adekurniasari@ gmail.com }}$
}

\begin{abstract}
Abstrak. Dalam penelitian ini yang menjadi masalah adalah kemampuan bercerita anak belum berkembang dengan baik.Karena kurangnya guru dalam menggunakan media pembelajaran yang bervariasi seperti penggunaan media pembelajaran media audio visual yang dimana media audio visual cukup banyak memberikan motivasi dalam kemampuan bercerita anak yang baik, karena mampu mengaktifkan kedua indera yaitu pendengaran dan penglihatan. Penelitian ini bertujuan untuk mengetahui pengembangan kemampuan bercerita anak di kelompok B di TK Aba 06 Cabang Medan.

Jenis penelitian ini adalah penelitian post test only control design. Penelitian ini bertujuan untuk mengetahui pengaruh media audio visual terhadap kemampuan bercerita anak di kelompok B di TK Aba 06 Cabang Medan.Penelitian ini dilakukan dengan menggunakan dua kelas kelompok yang memiliki karakteristik yang sama yaitu kelas B1 dan kelas B2. Penentuan sampel kelas dilakukan secara acak (random) dengan jumlah sampel tiap kelas sebanyak 20 anak. Variabel bebas adalah penggunaan media audio visual sedangkan variabel terikat adalah kemampuan bercerita anak. Intrumen pengumpulan data yaitu pedoman observasi. Analisis data mengunakan uji-t. Dan observasi dilakukan pengobservasi dengan pedoman observasi yang telah disediakan. Dengan taraf nyata $\alpha=0,05$. Berdasarkan hasil analisis data diatas diperoleh rata-rata nilai pada kelas eksperimen 10,05 dengan nilai tertinggi 12 dan nilai terendah 8 , sehingga pengembangan kemampuan bercerita anak pada kelas eksperimen memperoleh perbedaan yang signifikan. Sedangkan nilai rata-rata pada kelas kontrol 7,05 dengan nilai tertinggi 9 dan nilai terendah 5, sehingga pengembangan kemampuan bercerita anak pada kelas kontrol memperoleh perbedaan yang signifikan.

Berdasarkan hasil tersebut hipotesis menyatakan bahwa pembelajaran menggunakan media audio visual berpengaruh secara signifikan terhadap pengembangan kemampuan bercerita anak yaitu dari hasil uji hipotesis diperoleh $\mathrm{t}_{\text {hitung }}>\mathrm{t}$ tabel, yaitu 8,62 >1,72 pada taraf $\alpha=0.05$. Dengan demikian penggunaan media audio visual berperngaruh secara signifikan terhadap pengembangan kemampuan bercerita anak Kelompok B di TK Aba 06 Cabang Medan..
\end{abstract}

Kata Kunci: kemampuan bercerita anak, media audio visual

\section{PENDAHULUAN}

musfiroh (2005:27) berpendapat bahwa bercerita merupakan suatu cara berkomunikasi linguistik yang kuat dan menghibur serta dapat mengajarkan kepada siswa dalam mengenal ritme, pitch (pola titik nada) dan nuansa bahasa. Bercerita dalam konteks komunikasi dapat dikatakan sebagai upaya mempengaruhi orang lain melalui ucapan dan pemutaran tentang suatu (ide) pengalaman. Menurut Bactiar S. Bachri (2005:23) Sementara dalam konteks pembelajaran anak usia dini bercerita dapat dikatakan sebagai upaya untuk mengembangkan potensi kemampuan bahasa anak melalui pendengaran 
kemudian memutarkannya kembali dengan tujuan melatih keterampilan anak dalam bercakap-cakap untuk menyampaikan ide dalam bentuk lisan.

Dengan demikian bercerita adalah suatu metode pengembang bahasa yang dapat mengembangkan beberapa aspek fisik maupun psikologis bagi anak Taman Kanak-Kanak sesuai dengan tahap perkembangannya. Untuk kegiatan pendidikan di Taman KanakKanak bercerita adalah kegiatan yang dilakukan oleh guru kepada anak didik untuk menyampaikan materi pembelajaran dengan menarik. Namun demikian tidak menutup kemungkinan bercerita dapat dilakukan dihadapan anak didik oleh guru atau antar guru, orang tua murid, oleh anak didik itu sendiri atau antar anak didik atau anak dengan orang dewasa, untuk mendukung bercerita dapat menggunakan media audio visual gerak seperti dengan menonton TV, VCD, DVD dan Film animasi yang sesuai dengan perkembangan bahasa anak Taman Kanak-Kanak.

kemudian Bachri (2005:12) juga mengemukakan pendapatnya bahwa dengan peningkatan kemampuan berkomunikasi lisan melalui berbahasa akan dapat meningkat dengan terlatihnya anak dalam melakukan kegiatan mendengarkan, memberikan respon, memberikan jawaban dan lain-lain sebagai aktivitas anak dalam melakukan kegiatan bercerita. Selain itu dengan bercerita juga dapat memperbaiki kemampuan verbal yang dimiliki anak sehingga anak mampu berkomunikasi dengan baik kepada orang lain. Hasil penelitian Loban dalam (astuti 2012: 129) mengemukakan tentang kemampuan bercerita anak usia 5 dan 6 tahun sebagai berikut: "Suka bercerita dan umumnya bercerita kepada seseorang, tertarik menggunakan kata-kata baru dan luas, banyak bertanya, tata bahasa akurat dan beralasan, menggunakan bahasa yang sesuai, dapat mendefinisikan dengan bahasa yang sederhana, menggunakan bahasa dengan agresi, mengajukan pertanyaanpertanyaan, sangat aktif bercerita".

Media merupakan salah satu alat penyampaian materi kepada siswa. Media tidak hanya dipahami sebagai alat peraga, tetapi juga sebagai pembawa informasi atau pesan pengajaran kepada peserta didik. Miarso dalam Fadlillah (2012: 206), menyebutkan bahwa yang dinamakan media pembelajaran ialah segala sesuatu yang digunakan untuk menyalurkan pesan serta dapat merangsang pikiran, perasaan, perhatian, dan kemauan si pembelajar sehingga dapat mendorong terjadinya proses belajar yang disengaja, bertujuan, dan terkendali. Pendapat lain menyebutkan media adalah segala sesuatu yang dapat digunakan untuk menyalurkan pesan (materi pembelajaran), merangsang pikiran, segala sesuatu yang dapat digunakan untuk menyalurkan pesan, merangsang pikiran, perasaan, perhatian dan keterampilan siswa sehingga dapat mendorong proses pembelajaran.

Dalam dunia pendidikan, sumber (pemberi pesan) adalah guru, penerima pesan adalah anak didik, sedangkan informasi (pesan) adalah materi pelajaran yang harus disampaikan guru kepada anak didik. Dalam pengertian ini, guru, buku teks, dan lingkungan sekolah merupakan media. Secara lebih khususnya pengertian media dalam proses belajar mengajar cenderung diartikan sebagai alat-alat grafis, fhotografis, atau elektris untuk menangkap, memproses, dan menyusun kembali visual dan verbal

\section{METODOLOGI PENELITIAN}

Penelitian ini termasuk penelitian kuantitatif (eksperimen) dengan menggunakan desain penelitian posttest-only control design. Menurut sugiyono (2012:8) "metode penelitian kuantitatif berlandaskan pada filsafat positifisme yang digunakan untuk meneliti pada 
populasi atau sampel tertentu. dalam jenis penelitian ini terdapat kelompok eksperimen dan kelompok kontrol yang dipilih secara random". Menurut Sugiono (2012:80) "Populasi adalah wilayah generalisasi yang terdiri atas obyek/subyek yang mempunyai kualitas dan karakteristik tertentu yang ditetapkan peneliti untuk dipelajari dan kemudian di tarik kesimpulannya". Dari defenisi diatas maka populasi dalam penelitian ini adalah seluruh anak di Taman Aba 06 cabang medan. Adapun anak kelompok B terdiri dari 2 kelas yaitu kelas B1 berjumlah 20 anak, kelas B2 berjumlah 20 anak. Dengan jumlah keseluruhan anak sebanyak 40 anak.

Dalam penelitian ini teknik pengumpulan data yang digunakan adalah observasi. Metode observasi dilakukan dengan cara mengamati dan mencatat semua aktivitas anak pada proses kegiatan kolase di kelas. Observasi dilakukan pada anakkelompok Buntuk memperoleh data anak yang berkaitan dengan aspek-aspek kreativitas anak.Penyusunan data dilakukan dengan memuat namaanak.Tugas observer memberi tanda checklist $(\checkmark)$ pada skor yang di dapat melalui pedoman observasi yang dibuat. Dari observasi yang dilakukan maka diperoleh data tentang pengaruh darikegiatan kolase ampas kelapa terhadap kreativitas anak usia 5-6 tahun.

Tabel 1. Kisi - Kisi Perkembangan Kreativitas Anak

Kisi-kisi Instrumen kemampuan bercerita

\begin{tabular}{|c|c|c|}
\hline Variabel & Indikator & Deskriptor \\
\hline \multirow[t]{4}{*}{$\begin{array}{l}\text { 1.kemampuan } \\
\text { bercerita }\end{array}$} & $\begin{array}{l}\text { 1.Berkomunikasi } \\
\text { secara lisan }\end{array}$ & $\begin{array}{l}\text { 1. Anak dapat menyebutkan judul film dengan } \\
\text { benar } \\
\text { 2. Anak dapat menyebutkan nama dari salah } \\
\text { satu tokoh dalam film } \\
\text { 3. Anak dapat menyebutkan sifat tokoh film } \\
\text { sesuai dengan pengetahuannya }\end{array}$ \\
\hline & $\begin{array}{l}\text { 2.Menyusun } \\
\text { kalimat sederhana } \\
\text { dalam struktur } \\
\text { lengkap }\end{array}$ & $\begin{array}{l}\text { 1. Anak dapat mengulang sebuah kalimat } \\
\text { yang ada dalam dialog film dengan lancar } \\
\text { seperti dialog "dennis" } \\
\text { 2. Anak dapat Bercerita dengan menggunakan } \\
\text { kata ganti aku, saya, kamu, dia, mereka. } \\
\text { 3. Anak dapat bercerita dengan nada suara } \\
\text { berbeda meniru nada suara karakter tokoh } \\
\text { dalam film. }\end{array}$ \\
\hline & $\begin{array}{l}\text { 3.Menjawab } \\
\text { pertanyaan yang } \\
\text { lebih kompleks }\end{array}$ & $\begin{array}{l}\text { 1. Anak dapat mengungkapkan perasaannya } \\
\text { (suka/ tidak suka) terhadap cerita film } \\
\text { 2. Anak dapat menjawab pertanyaan apa, } \\
\text { mengapa, dimana, berapa, dan bagaimana, } \\
\text { mengenai isi cerita dalam film. } \\
\text { 3. Anak dapat menjelaskan dengan singkat } \\
\text { karakter tokoh dalam film }\end{array}$ \\
\hline & $\begin{array}{l}\text { 4.Mengulang } \\
\text { kembali kalimat } \\
\text { yang lebih } \\
\text { kompleks }\end{array}$ & $\begin{array}{l}\text { 1. Anak dapat menceritakan kembali awal } \\
\text { cerita dalam film kepada gurunya } \\
\text { 2. Anak dapat menceritakan kembali awal } \\
\text { cerita dalam film kepada temannya } \\
\text { 3. Anak dapat mengucapkan kembali bahasa } \\
\text { dari salah satu tokoh yang di sukainya. }\end{array}$ \\
\hline
\end{tabular}




\section{HASIL DAN DISKUSI}

Seperti yang telah dijelaskan pada bab III bahwa data dalam penelitian ini dikumpulkan dengan tehnik observasi. Pedoman observasi telah dirancang sedemikian rupa sehingga dapat digunakan untuk menjaring data kemampuan bercerita anak.

Berdasarkan hasil analisis diketahui bahwa Kemampuan Bercerita anak pada kelas eksperimen dinyatakan baik. Pengolahan data kemampuan bercerita anak di peroleh skor tertinggi 12 dan skor terendah 8 dengan nilai rata-rata 10,05 dan standar deviasi 1,31. Rata-rata hitung lebih rendah dari rata-rata ideal, dari deskripsi diketahui kemampuan bercerita anak belum maksimal berkembang di karenakan kemampuan becerita anak masih dalam perkembangan.

Berdasarkan hasil analisis data kelas kontrol yang di peroleh dari penelitan maka dapat diketahui kemampuan bercerita anak pada kelas kontrol dinyatakan cukup. Dari hasil pengolahan data kemampuan bercerita di peroleh skor tertinggi 9 dan skor terendah 5 dengan nilai rata-rata 7,05 dan standar deviasi 1,23. Rata-rata hitung lebih rendah dari ratrata ideal, dari deskripsi di ketahui kemampuan bercerita anak belum maksimal berkembang dikarenakan kemampuan bercerita anak masih dalam perkembangan.

Untuk melihat perbandingan nilai rata-rata yang diperoleh anak pada kelas eksperimen Dan kelas kontrol dilihat dari pada tabel berikut:

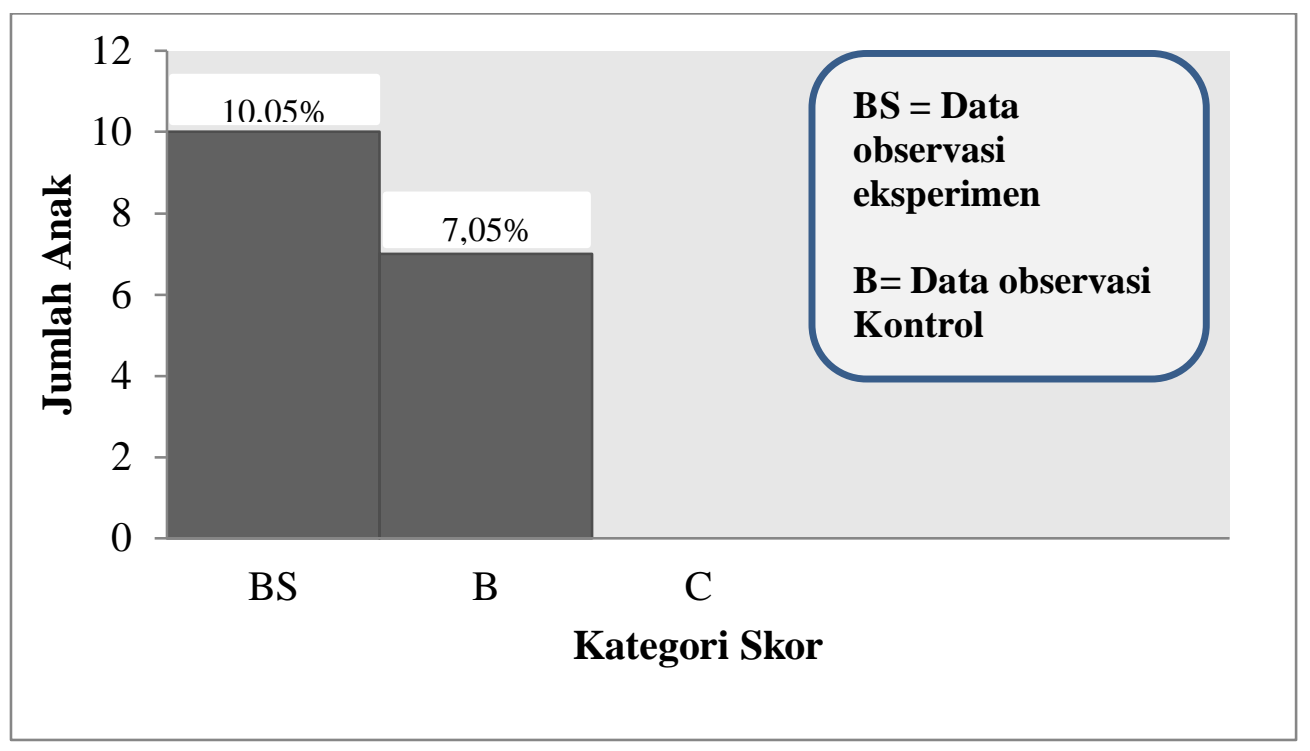

Gambar 1. Histogram Hasil Penelitian Kemampuan bercerita Anak Kelas Eksperimen Dan Kelas Kontrol

\section{PEMBAHASAN}

Pembelajaran dengan menggunakan media yang bervariasi akan menimbulkan motivasi anak untuk mengikuti pembelajaran. hal ini, sangat berpengaruh terhadap segala aspek perkembangan anak baik dalam aspek bahasa, kognitif, afektif dan psikomotorik. Dengan demikian tujuan yang ingin dicapai pada pembelajaran tercapai dengan baik dan sesuai harapan. 
Setelah dilakukan yang berbeda diperoleh skor kemampuan bercerita anak di kelas eksperimen 10,05 sedangkan kelas kontrol 7,05. Rata-rata hitung pada kelas eksperimen dan kontrol lebih rendah dari rata-rata ideal, dari deskripsi diketahui kemampuan bercerita pada anak belum maksimal dikarenakan kemampuan bercerita pada anak masih dalam perkembangan. Dari hasil observasi kedua sampel tersebut diperoleh selisih 3 dari data yang diperoleh tersebut terdapat perbedaan yang signifikan antara kemampuan bercerita pada kelas eksperimen dan kontrol.

Hasil penggunaan media audio visual gerak pada kelas eksperimen ternyata cukup memuaskan anak pada kelas eksperimen dibandingkan dengan kelas kontrol. Hal ini dapat disebabkan karena pengaruh media audio visual yang menarik bagi anak usia 5-6 tahun, dengan adanya sarana pembelajaran berupa media audio visual anak memperoleh kebebasan untuk berekspresi dalam menggunakan bahasanya dan lebih percaya diri karena pada metode ini anak tidak dituntut akan benar salah namun memberikan motivasi yang lebih kepada anak untuk mengembangkan kemampuan bercerita sesuai dengan pengalaman anak sehari-hari.

Berdasarkan hal tersebut dapat dikatakan bahwa media audio visual mempunyai fungsi dalam perkembangan pembelajaran anak. Jadi, dapat dikatakan bahwa penggunaan media audio visual gerak pada penelitian ini memberikan dampak positif terhadap peningkatan kemampuan bercerita anak usia 4-5 tahun di TK ABA 06 CABANG MEDAN.

\section{SIMPULAN}

Berdasarkan hasil penelitian dan pengolahan data pada sub bab sebelumnya dapat di ambil kesimpulan, yaitu : Hasil analisis deskriptif data hasil observasi pada kelas eksperimen yang memanfaatkan media audio visual gerak lebih baik/tinggi di bandingkan dari kelas kontrol. Skor tertinggi kelas eksperimen 12, kelas kontrol 9. Ratarata kelas eksperimen 10,05, untuk kelas kontrol 7,05. Kondisi kemampuan bercerita anak usia 4-5 tahun sesudah menggunakan media audio visual berupa film dalam bentuk VCD dan DVD mengalami kemampuan bercerita. Anak sudah dapat menggunakan dan menerima kalimat sederhana dengan baik dan benar, dan mampu mengungkapkan perasaanya seperti rasa simpati dan empati.

Berdasarkan kesimpulan diatas, maka peneliti mengajukan beberapa saran yaitu :

1. Bagi guru disarankan untuk menggunakan media audio visual sebagai media pembelajaran untuk dapat meningkatkan kemampuan bercerita anak usia 4-5 tahun, karena media audio visual menggunakan indera penglihatan dan pendengaran.

2. Bagi orang tua dapat menambah pengetahuan terkait penggunaan media audio visual untuk dapat mengembangkan kemampuan bercerita anak usia dini.

3. Bagi kepala sekolah diharapkan dapat menyediakan bahan-bahan media audio visual sebagai alat pembelajaran untuk meningkatkan kemampuan bercerita anak usia dini.

4. Bagi Peneliti lain sebagai bahan masukan dan sumber referensi yang melakukan penelitian yang ada hubungannya dengan Pengaruh media audio visual terhadap kemampuan bercerita anak di kelompok B. 


\section{DAFTAR RUJUKAN}

Arsyad, Azhar. 2008. Media Pembelajaran. Jakarta: Raja Grafindo Persada Anitah, S. (2009). Media Pembelajaran. Surakarta: Mata Padi Presindo Azhar Arsyad. 2004. Media Pembelajaran. Jakarta: PT Raja Grafindo Persada Arikunto, Suharsimi. 2006. Manajemen Penelitian. Jakarta: Rineka Cipta Bachri, B.S. (2005). Pengembangan Kegiatan Bercerita di Taman Kanak-kanak Teknik dan Prosedurnya. Jakarta: Depdiknas

Depdiknas. 2004. “Aplikasi dan Aplikasi Pendidikan”. Bandung: Imperial Bhakti Utama

Depdiknas, 2000. Kamus Besar Bahasa Indonesia. Jakarta: Universitas Terbuka

Dahlan. 2013. Meningkatkan Kemampuan Bahasa Melalui Metode Bercerita

Dengan Media Audio Visual Di Kelompok B1 Ra PERWANIDA 02 Slawi. Skripsi Program Studi Pendidikan Guru Pendidikan Anak Usia Dini Univesitas Negeri Semarang. Skripsi tidak di terbitkan

Dhieni Nurbiana, dkk. 2008. "Metode Pengembangan Bahasa". Jakarta: Elangga

Depdiknas, Kurikulum 2004 Standard Kompetensi Tk Dan Ra.Dirjen Dikdasmen, Jakarta, 2005

Hamdani. (2011). Media Pembelajaran. Jakarta: PT. Raja Grafindo Persada

Hurlock. 2008. Perkembangan Anak (Edisi keenam). Jakarta: Erlangga

Kartini.(2007). Model Pembelajaran Atraktif di Taman Kanak-Kanak. http://tikkysuwantikno.wordpress.com/2007/12/27/model-pembelajaran-atraktifdi-taman-kanak-kanak/ Diakses 15 Juli 2016.

Munadi, Y. (2013). Media Pembelajaran Sebuah Pendekatan Baru. Jakarta: Referensi

Mulyati, Yeti, dkk. 2013. Bahasa Indonesia. Jakarta: Universitas Terbuka Masitoh, dkk. 2006. Strategi pembelajaran TK. Jakarta:Universitas terbuka Musfiroh, T. 2005. Bercerita Untuk Anak Usia Dini. Jakarta: Depdiknas

Susanto, Ahmad. 2011. Perkembangan Anak Usia Dini. Jakarta: Kencana Prenada Media Group

Sugiyono. 2012. Metode Penelitian Kuantitatif, Kualitatif dan $R \& D$. Bandung:Alfabeta Sujiono,dkk.2010. Bermain Keatif Berbasisi Kecerdasan Jamak.Jakarta Sudjana. 2005. Metode Statistik. Bandung: Tarsiti Bandung

Tampubolon. 1991. Mengembangkan Minat dan Kebiasaan Membaca pada anak. Bandung : Angkasa

Wothman. 2013. Media Pembelajaran. Jakarta: Raja Grafindo Persada Yulianti, Dwi.2010. Bermain sambil Belajar Sains. Jakarta: Indeks 